\title{
Preserving the values of cultural negotiation through social learning: 'Two Religion Community Life' case study in Phattalung, Southeast Thailand
}

\begin{tabular}{|c|c|}
\hline \multicolumn{2}{|c|}{$\begin{array}{l}\text { Authors: } \\
\text { Sri Sumarni }{ }^{1} \text { (I) }\end{array}$} \\
\hline $\begin{array}{l}\text { Affiliations: } \\
{ }^{1} \text { Master of Isl } \\
\text { Elementary T } \\
\text { Education, Fa } \\
\text { Education anc } \\
\text { Training, Univ } \\
\text { Negeri Sunan } \\
\text { Yogyakarta, In }\end{array}$ & $\begin{array}{l}\text { mic } \\
\text { acher } \\
\text { ulty of Islamic } \\
\text { Teacher } \\
\text { ersitas Islam } \\
\text { Kalijaga, } \\
\text { donesia }\end{array}$ \\
\hline \multicolumn{2}{|c|}{$\begin{array}{l}{ }^{2} \text { Master of Political Science } \\
\text { Program, Faculty of Liberal } \\
\text { Arts and Social Sciences, } \\
\text { Fatoni University, Pattani, } \\
\text { Thailand }\end{array}$} \\
\hline \multicolumn{2}{|c|}{$\begin{array}{l}\text { Corresponding author: } \\
\text { Sri Sumarni, } \\
\text { marni.suka@gmail.com }\end{array}$} \\
\hline $\begin{array}{l}\text { Dates: } \\
\text { Received: } 24 \\
\text { Accepted: } 03 \\
\text { Published: } 27\end{array}$ & $\begin{array}{l}\text { an. } 2020 \\
\text { Apr. } 2020 \\
\text { July } 2020\end{array}$ \\
\hline \multicolumn{2}{|c|}{$\begin{array}{l}\text { How to cite this article: } \\
\text { Sumarni, S. \& Kalupae, A.K., } \\
\text { 2020, 'Preserving the values } \\
\text { of cultural negotiation } \\
\text { through social learning: } \\
\text { 'Two Religion Community } \\
\text { Life' case study in Phattalung, } \\
\text { Southeast Thailand', } \\
\text { HTS Teologiese Studies/ } \\
\text { Theological Studies } 76(1), \\
\text { a5947. https://doi.org/ } \\
\text { 10.4102/hts.v76i1.5947 }\end{array}$} \\
\hline \multicolumn{2}{|c|}{$\begin{array}{l}\text { Copyright: } \\
\text { (c) 2020. The Author } \\
\text { Licensee: AOSIS. Thi } \\
\text { is licensed under the } \\
\text { Creative Commons } \\
\text { Attribution License. }\end{array}$} \\
\hline \multicolumn{2}{|l|}{ Read online: } \\
\hline 回神回 & $\begin{array}{l}\text { Scan this QR } \\
\text { code with your } \\
\text { smart phone or } \\
\text { mobile device } \\
\text { to read online. }\end{array}$ \\
\hline
\end{tabular}

Prolonged conflict on the southern Thailand border still continues, especially in four provinces Pattani, Yala, Narathivat, and Satun. These four provinces are the home base of the Malay-Muslim community. However, conflicts have almost never occurred in the province of Phattalung, particularly in the region called 'Two Religion Community Life'. This is because people can find solutions to every problem using cultural negotiation. This research aims to describe the results of cultural negotiation and social learning between Muslims and Buddhists in solving daily life problems. The most important data collection techniques are in-depth interviews and observations. There are five critical informants chosen purposively: Islamic and Buddhist religious leaders, community leaders, school principals, and community members in the Tamot and Khaocan regions. The results found that there are several forms of cultural negotiation in Phattalung, including annual ritual prayers conducted together by Muslims and Buddhists, agreement on how to slaughter animals to be served during ceremonies, tradition of food bartering, and agreement on animal caring. Furthermore, social learning to preserve the results of the negotiations is carried out through the establishment of voluntary medical groups whose members consist of young men and women from the Muslim and the Buddhist community, sports and arts activities, commemorations of national holidays, and conducting annual religious rituals at the same place and time. This study also found four important aspects to strengthen the social learning in multireligious society moderate values derived from their respective religious teachings, moderate values taught by the country, the existence of trust among citizens, and win-win solutions to the emerging problems.

Contribution: This research promotes the world that there is a heterogeneous religious community in the Phattalung province, Thailand which has a building construction of tolerance and harmony of locality namely the 'Two Religion Community Life' by preserving the cultural negotiation values through social learning.

Keywords: cultural negotiation; moderate values; social learning; two religion community life; multicultural society.

\section{Introduction}

In daily life, religion needs culture as a social basis to become a medium for the actualisation of its teachings (Christie, Gunton \& Hejnowicz 2019; Rissanen 2020). When the appreciation of religious diversity is sustainably manifested in a culture over a long period of time, there is cultural negotiation (Sadr 2020; Shanks 2019).

This happened between the Muslims and Buddhist communities in Tamot, Southern Thailand, especially in a region called 'Two Religion Community Life'. Cultural negotiation is frequently related to difference in religions. Silvestri and Mayall (2015) discussed three cases of conflict, namely Israel-Palestine, Mali, and Bosnia-Herzegovina. They pointed out that conflict between religious communities is relative and contextual. Understanding a conflict between religious communities needs to trace the long history of why such conflict happened and how the conflict was connected to the local area and its surroundings (Silvestri \& Mayall 2015). Therefore, religion can be both a source of peace and a cause of conflict.

Likewise, the differences between Buddhist and Muslim identity for several countries in Asia must be approached by cultural negotiations based on shared values (Frydenlund \& Jerryson 2020). Kung (1997) called it global ethics - the general standard that must be upheld in the life of religious communities. Building a positive future requires transcending the past through developing a relationship between Buddhism and Islam as civilisations, not as provincialisms (Kung 1997; Radhakrishnan 2019; Saffari 2019). 
Consequently, global ethics teach that peace between the world's religions will not be created without continuous dialogue and negotiation until new norms are agreed.

The occurrence of cultural negotiation depends on the process of adaptation of a person or a community to their environment (Chatterjee 2006; Comberti et al. 2019; Thornton et al. 2019). Furthermore, the adaptation process is affected by a broad sociocultural context. On the other hand, the results of Frounfelker's research on parent-child relationships in the United States have proved that differences in individual experiences have been a cause of tension in the relationship between children and parents (Frounfelker et al. 2017). In this case, it can be concluded that the more experience a person has from his and/or her environment, the more adaptive he and/or she is in making change.

Relevant to the Frounfelker et al. (2017) findings, Brett (2010) studied cultural negotiations that connect negotiation, power, and information. He stated that the more egalitarian a society is, the more easily the negotiation process happens. Moreover, the more information shared by both parties, the more smoothly and easily the negotiation process runs. These conclusions reinforce the research findings that negotiation is contextual. It depends on sharing information on each different identity, whether culture or religion (Chatterjee 2006). Negotiation is also strongly influenced by the negotiator's ability and motivation to find information about the identity and the causes of conflict from both parties (Brett 2010; Qurtuby 2013).

Information about the uniqueness of two or more parties in the context of diversity is needed in the effort to understand each other's identities (Swasgita 2017). The effort to understand each other is the entrance to the process of identity negotiation.

Cultural negotiation often occurs in multicultural communities that are vulnerable to conflict (Zaw 2019; Zhao, Chen \& Li 2020). Preservation of the negotiation results can be done through sustainable social learning among the diverse groups to avoid problems which may emerge (Chatterjee 2006). Therefore, the results of cultural negotiation need to be preserved to maintain harmony in the community.

The preservation of the results of negotiation through social learning is important to maintain harmony in the life of the community in order to create a peaceful atmosphere (Laiti \& Frangou 2019). Social learning can give meaning to humans if they are able to learn from the experiences of others (Shusterman 2010). This is what is called learning from experience.

Humans can accumulate experiences that continue to grow over time by learning (Nabavi 2012; Pierce \& Bandura 1977). Links between the accumulation of existing experiences and new experiences will make the difference. That is why knowledge is cumulative and is obtained through a collective process (Stromquist 2014). Therefore, this research aims to describe the results of cultural negotiations between Muslims and Buddhists, as well as the preservation process through social learning, in the 'Two Religion Community Life' region in Tamot, Phattalung, Southern Thailand.

\section{Research method}

This study intends to describe in depth the phenomena that exist in social reality in order to obtain meaning from a life context (Bungin 2007). Furthermore, the model used is Alfred Schutz's phenomenological model, which understands a symptom of the motives, desires, and meanings of people's actions in everyday life (Natanson 1966; Nindito 2013). Therefore, this study explains the meaning given by Muslims and Buddhists about their religious practices - especially relating to their association with followers of other religions. It explains, for example, how Muslims and Buddhists can be open with each other, can talk in order to unravel each other's identity, how negotiations are achieved, and how they are preserved.

The most important data collection techniques are in-depth interviews and observations. The technique of determining the subject of research uses purposive sampling. Interviews were conducted with key informants, namely Islamic religious leaders (Kyai, Mufti) and Buddhist leaders (Bikkhu), community leaders, school principals in the region, and community members (lecturers, teachers and Kyai children) in the Tamot and Khaocan regions, Phattalung, Southern Thailand. During the interview, the researcher also noted observers' expressions, moods, symbols or artifacts, such as the state of the house, school, mosque, temple, place of praying together, shared burial place, and so on. The results of these observations are also used to conduct data validation for interviews, or vice versa, while data analysis uses an interactive analysis model from Miles and Huberman, which consists of data reduction, data presentation, and conclusion drawing (Miles, Huberman \& Saldana 2018).

\section{Results and discussion}

\section{Multireligion community, cultural negotiation, and social learning}

Religion is an important determinant of people's lifestyles, perspectives, attitudes and behaviours (Altun et al. 2018). Religion can also be a major factor in developing identity and culture. Appleby (2000) pointed out two dimensions of religion - that religion can be a factor of conflict and violence and also be a factor of peace and reconciliation. Gutmann (2003) developed optimism that the meeting of these two concepts would strengthen the establishment of justice and the stronger individual guarantees. Some people criticise the fact that religion tends to build tyranny. Gutmann, however, believed that it is not only religion that has the potential to build tyranny, but also many cultures, beliefs, and systems in an identity, which have the same potential when not appreciating each individual (Gutmann 2003).

The optimism addressed by Appleby (2000) and Gutmann (2003) was elaborated by Yusuf (2009) about moderate values in two religions. In Buddhism, people know the term of Majjhima-Patipada - the middle way; while in Islam, people also know about the term of Ummatan Wasatan - the middle people (Yusuf 2009). This teaching emphasises moderate values and offers a strong foundation to encourage cooperation 
among different religious communities. This is important because the aim of establishing a peaceful relationship between different religious communities is something which has become urgent from time to time for the advancement of civilisation. Dialogue between monotheistic religions in Asia requires initiative from moderate monotheism (Swasgita 2017). When the dialogue reaches an agreement, the task of the community is then to preserve it through social learning by creating various activities together to maintain peace and advance civilisation (Tremblay, Magnan \& Levasseur 2018).

World civilisation can exist only through peace. However, it is inevitable that problems often arise in diverse religious communities as a result of differences in identity which are often difficult to negotiate. In general, the difficulty in negotiating is experienced because the different communities do not understand each other and have not taught each other optimally, because each community keeps its distance. Nugroho (2014) and Abdullah (2013) explained that the relationship between understanding of other religions with mutual respect behaviour can be categorised into three groups, namely: (1) vulnerable to conflict groups which keep their distance, (2) neutral groups, and (3) mutually supportive or tolerant groups.

In order to create mutually beneficial, mutually supportive, and mutually supportive relationships between parties of different religions, meeting spaces are needed so that they can engage, learn from each other, increase dialogue, and negotiate becoming multireligious communities. Therefore, they can relax the tyranny of identity and can agree upon the same norms and values and ultimately become a shared culture.

Both before and after negotiations, multireligious communities continue to provide space to meet each other and learn from each other's identities, so that it will be easy to be open to change (see Figure 1). The process of mutual understanding of these differences is referred to as formal and informal socialisation (Tremblay et al. 2018).

In a negotiation, the role of the negotiator or mediator is very important. A negotiator is a person representing each conflicting party in the discussion, while a mediator is a third party to bridge the conflicting parties in the discussion. Tu and Chih in their research analysed the influence of religious culture on negotiations.



FIGURE 1: Relation among multireligious community, cultural negotiation, and social learning.
$\mathrm{Tu}$ and Chih use the four negotiation styles of Casse and Deols, namely: factual style, normative style, intuitive style, and analytical style. The study concluded that religious culture was a significant variable that influenced the factual, normative, intuitive, and analytical negotiating styles (Tu \& Chih 2011). There are similarities between Buddhists and Muslims in negotiations because both use a more normative and intuitive style, so the negotiations between the two groups experienced great success.

The role of negotiator is very important to the result of negotiations: (1) win-win, (2) win-lose, or (3) lose-lose. The negotiator's or mediator's understanding of the issue being disputed is very important. These roles are usually taken by formal community figures (community leaders) and nonformal figures (e.g. clerics, monks, priests, or another important figures in the community). These community leaders and religious leaders are generally used as models in social learning (Brett, Gunia \& Teucher 2017; Wertheim 2017).

In social learning, an individual will learn a lot from his environment through the experience of others, both individually and together. It means that learning can happen anywhere, not only at schools but also in the community. This idea is also in line with the idea of the three education centres envisaged by $\mathrm{Ki}$ Hajar Dewantara, an Indonesian education hero, who stated that education may happen in the family, the school, and the community (Hidayati 2016). Dewey stated that learning becomes a process of continuous renewal for the sustainability of the community and its members in dealing with life problems (Hansen 2002). Besides Dewey, Bandura is also an expert who is concerned with social learning theory where behaviour is the result of mutual interaction between experience, environment, and cognitive-personal influence (Nabavi 2012; Pierce \& Bandura 1977). Environment can be a reality or a model. The model to be imitated is not necessarily a person, but also the other symbolic model (Blute 1981). Therefore, it can be said that there are direct socialisation and negotiation processes in social learning, especially to solve problems in daily life (Tremblay et al. 2018).

Oman (2013) argued that social learning must be considered among the major candidates for explaining why and how people become spiritual or religious, and why their spirituality or religion assumes a form. A social learning view of spiritual and religious engagement is also achievable in many practical applications. It may be used by people who seek to deepen their own learning of spirituality or religion as well as by human services professionals who have identified spiritual or religious factors as relevant to client wellbeing (Oman 2013). For millennia, social learning has been of interest to religious and spiritual teachers and educators. Religious educators often place high value on the power of example, saying that religion and spirituality are 'caught, not taught'.

\section{The results of cultural negotiation and social learning in Phattalung province}

Phattalung province in southern Thailand is located approximately $850 \mathrm{~km}$ south of Bangkok and $200 \mathrm{~km}$ north of the Phattani region (PeoPlaid 2018). It is a beautiful region 
supported by the history of classic Islam in Malaysia Peninsula. From ancient times until now, Phattalung has been closely related to the Songkhla province, especially in terms of geography and cultural history, because during the Sriwijaya Kingdom (around the 7th century), the people of Phattalung and Songkhla received the influence of Indian culture in Mahayana Buddhism. Phattalung is one of the 14 provinces in the southern Thailand region.

Phattalung, Songkhla, and Nakhonsrithammarat are provinces in southern Thailand where Buddhists constitute the majority (approximately 95\%) and Muslims are a minority (approximately $5 \%$ ). However, in some districts, Buddhists and Muslims are equal in number, living in a mixed environment in the context of daily life. In some regions, these communities have become more clearly separated internally by their religious identity. For instance, Ban Tamot is a Buddhist community, while Ban Hua Chang is a Muslim community (Horstmann 2011).

In Phattalung province, there is a region called 'Two Religion Community Life', found in Tamot (see Figure 2). The history of this community is related to the history of the family of Tuk Mahmud, where his children were later converted to Buddhism. This has lasted until now, showing the existence of social harmony in this region.

In this region, Buddhist temples were built on the remains of a Muslim cemetery and mosque, while Ban Hua Chang, which was once a Buddhist settlement, is now a Muslim



Source: Photo taken by author

FIGURE 2: Road sign to the region of 'Two Religion Community Life'. settlement. Formerly, the Tamot cemetery was used as a Muslim cemetery, but gradually it was also used as a burial place for the Buddhist population. Thus, Muslims and Buddhists have the same burial place (see Figure 3).

In the fifth lunar month every year, there is a joint praying ritual between Muslims and Buddhists at this burial place (see Figure 4). The ritual ceremony was attended by the residents of Tamot as well as many visitors who wished to observe this unique ceremony. The praying ceremony of Muslims and Buddhists in this region can be an important social learning medium for passing down noble values, especially values related to tolerance.

At the annual ritual, residents of the surrounding community, consisting of Muslims and Buddhists, arrive to a greeting presented by a religious leader in Malay as follows:

Ucap salae yang guna umum dan dibiasa'ae oleh keraja'ae adalah 'sawaddee', walau bagaimanapun sama muslim ucapae 'assalamu'alaikum'. [The common greeting which is generally applied and taught by the Thai Kingdom is 'Sawasdee', which means wellbeing, while greeting to the fellow Muslims is pronounced 'Assalamu'alaikum']. (U.K. Ahmad, pers. comm., 06 November 2017)

The greeting culture can be used as ethical learning from parents to children, from generation to generation, by not

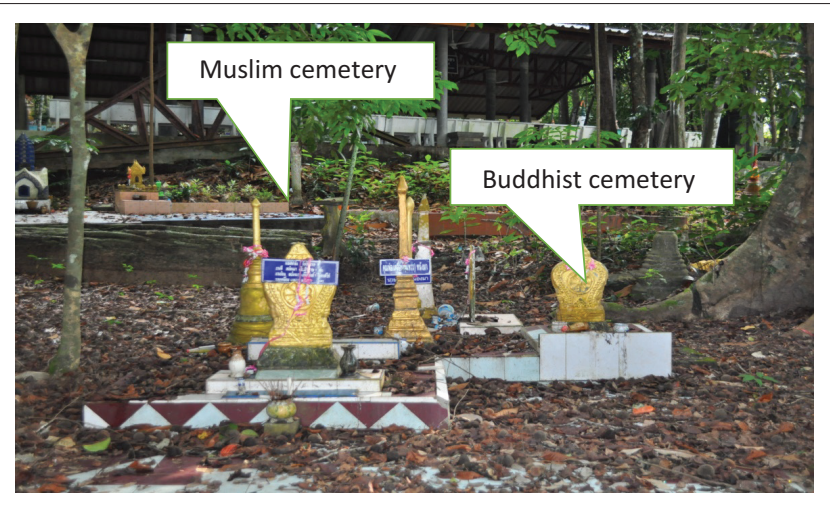

Source: Photo taken by author

FIGURE 3: Shared cemetery for Muslims and Buddhists in Tamot, Phattalung, Thailand.

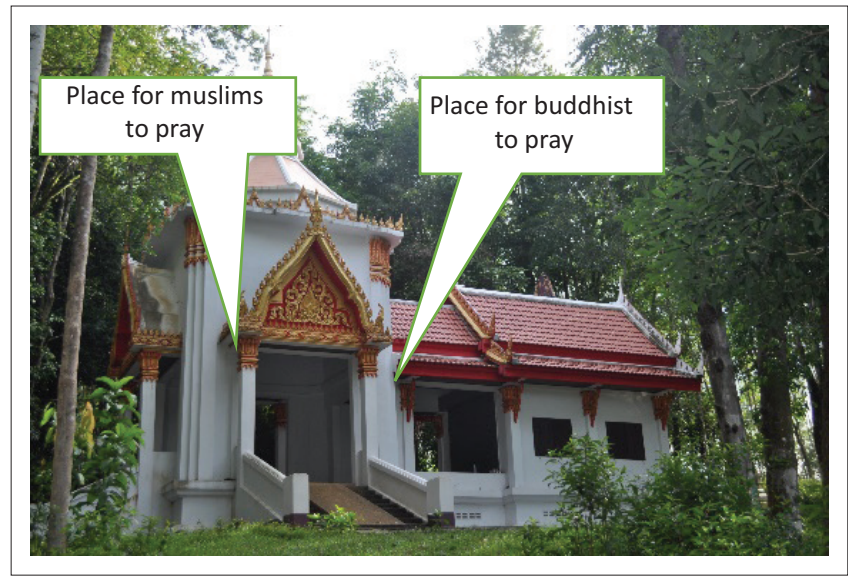

Source: Photo taken by author

FIGURE 4: The praying place for Muslims and Buddhists. 
looking at differences in religion, ethnicity, or language, because greeting is a cultural ethic and has become a common habit in all religions and nations in the world. Greetings are usually accompanied by a smile, also marking the sincerity of the relationship. Greeting people is also interpreted as a wish for safety and health for the person being addressed. In Tamot, the habit of smiling and greeting is still very strong and taught from generation to generation even though they have different religions. Every generation still practises the culture of smiles and greetings, because they feel they are still one family. They are united by an awareness of ancestral similarities.

In the relationship among religious communities, smiles and greetings can be a symbol of positive relationship, harmony, mutual support, respect, and acceptance of someone. In Tabanan Bali, Indonesia, there has also been a tolerance of Hindus and Buddhists by using the same place of worship and being taught from generation to generation (Swasgita 2017). At present, however, there is a fear that globalisation and industrialisation will reduce these three habits. Therefore, cultural inheritance through social environments which could provide learning to younger generations is very important. This is supported by Bandura's theory of social learning (Nabavi 2012).

Collaboration between community members in Phattalung was also shown at a joint prayer at an annual event located near the cemetery (see Figure 4). The Muslim prayer was guided by a cleric in Arabic, while the Buddhist prayer was guided by a Buddhist monk in Sanskrit, calling to one another in this cemetery. After the ritual was over, both Muslims and Buddhists bartered food. By having fun together, greeting, and bartering food, one can build a sense of brotherhood and harmony. Horstmann (2011) illustrated that the people join in prayer and food exchange as if they were on a vacation.

Besides the annual ceremony, there is also another result of negotiation that has been agreed between Muslims and Buddhists in this region. First, in preparing meals for ceremonies, the religious leaders said as follows:

Pada mulonya setiap orea Budha menjemput pesta (seperti pernikahea) orea Islam, tidak nak makea daging yang di hidea, kerana aga tidak halal kerana semeleh tidak baca 'bismillah' hal ini jadi pemikirea pemimpin agama dan mareka melaku runding sama orea kampung, dan telah putuskea bahwa jika orea Budha punya hajat, kemuadiea yang semeleh hewan pesta dilakukea oleh orea Islam [In the past, when a Buddhist hosted a party [e.g. wedding], Muslims did not consume meat served in the event since they consider the animal slaughtering is unlawful due to not mentioning 'Bismillah' while slaughtering. This event came into religious leaders' thought, Muslim and Buddhist. Then, they communicate this issue (animal slaughtering and cooking process) along with community representatives]. (U.K. Ahmad, pers. comm., 07 November 2017)

Through the negotiation process guided by religious leaders, an agreement was reached that the slaughtering of animals would be carried out by Muslims, and then they could cook together. Since then, Muslims have been willing to eat the meals served by their fellow Buddhists (U.K. Ahmad, pers. comm., 07 November 2017). This agreement is a manifestation of the sacrifice of both parties and the values of deep tolerance. This negotiation is similar to the negotiation between Buddhists and Hindus in Tabanan, Bali, as they share the same place of worship for Buddhists and Hindus, although the place of worship in Tamot is separated (Swasgita 2017).

Second, another problem that has occurred between Muslims and Buddhists in Khaocan village is the problem of petting dogs. Problems occur when there are people who bring their dogs to play in the Muslim village, thus igniting the anger of Muslim citizens. Some Muslims met with religious leaders to report the incident. Negotiations were carried out between Muslim and Buddhist religious leaders and community members and resulted in an agreement that all citizens who kept dogs would not bring them to Muslim settlements, and if they still brought their dog, they would be sanctioned (Ahmad et al. 2017). Table 1 presents the cultural negotiations and social learning.

Horstmann (2011) has researched in this region, suggesting that identity negotiation efforts can be made through art or religious rituals. In more detail, Horstmann said that body expressions, such as body movements, dances and songs, and similar forms of entertainment, communicated in the context of a performance, can be a tool for the process of negotiating identity. Horstmann provided an example of the case of praying interchange in the 'ritual of two religions' every year in Tamot, Patthalung, and the case of a Muslim woman who wanted to heal her child in a Buddhist temple in Songkhla, describing what is called the simultaneous presence of antagonism and tolerance in a multi-religious ritual space (Horstmann 2011). Where Horstmann focused on the relationship of cultural and artistic expression of Muslims and Buddhists in carrying out religious rituals, this research focuses more on revealing the results of cultural negotiations

TABLE 1: Cultural negotiation and social learning

\begin{tabular}{|c|c|c|c|}
\hline Number & Problems & Negotiation & Social learning \\
\hline \multirow[t]{3}{*}{1} & $\begin{array}{l}\text { Descendants } \\
\text { following diverse } \\
\text { religions (Islam and } \\
\text { Buddhist) are } \\
\text { vulnerable to conflict. }\end{array}$ & $\begin{array}{l}\text { Shared annual } \\
\text { ceremony }\end{array}$ & $\begin{array}{l}\text { Meeting families, creating } \\
\text { happiness, introducing } \\
\text { children to the long-time- } \\
\text { no-see family members, } \\
\text { building unity and } \\
\text { cooperation, and training } \\
\text { the children to maintain } \\
\text { the fellowship }\end{array}$ \\
\hline & & Shared cemetery & $\begin{array}{l}\text { Reducing the gap of } \\
\text { difference and building } \\
\text { unity }\end{array}$ \\
\hline & & Food bartering & $\begin{array}{l}\text { Reducing the gap of } \\
\text { difference and building } \\
\text { unity, developing open } \\
\text { attitudes }\end{array}$ \\
\hline 2 & $\begin{array}{l}\text { Muslims were } \\
\text { unwilling to eat the } \\
\text { feast in a ceremony } \\
\text { because of the } \\
\text { unlawful practice of } \\
\text { slaughtering animals. }\end{array}$ & $\begin{array}{l}\text { Agreement that } \\
\text { Muslims will be the } \\
\text { ones slaughtering } \\
\text { the animals }\end{array}$ & $\begin{array}{l}\text { Collaboration in holding } \\
\text { events, building unity } \\
\text { among adults and parents }\end{array}$ \\
\hline 3 & $\begin{array}{l}\text { Playing with dogs } \\
\text { and taking them to } \\
\text { the Muslim area }\end{array}$ & $\begin{array}{l}\text { Setting regulations } \\
\text { with regard to } \\
\text { petting dogs }\end{array}$ & $\begin{array}{l}\text { Reducing wounding } \\
\text { behaviour, revenge, and } \\
\text { conflict }\end{array}$ \\
\hline
\end{tabular}


and social learning as well as elements of learning reinforcement to shape mutual respect behaviour. The forms of relationship between Muslim and Buddhist citizens in negotiating their identities are examined and their possibilities identified as reinforcing elements of social learning.

\section{Social learning through youth activities}

To prepare a tolerant generation, a local tolerance that grows and lives in society can be a medium for learning reinforcement. The local traditions become a treasure in building harmony in a multi-ethnic and multi-religious society. An illustration of the community-building construction of tolerance and harmony of locality can be seen in the 'Two Religion Community Life' region in Tamot, Phattalung, Thailand. The harmony was built through cultural negotiations that have been continuously traded for decades. These local cultural traditions should be maintained and passed on from generation to generation through social learning.

Social learning in Tamot and its surrounding areas happens in various social activities, as a means of getting to know and to understand each other, including: (1) meeting of young men and women in health volunteer groups consisting of Muslims and Buddhists; (2) sports events such as soccer and sepak takraw (kick volleyball); (3) art activities, especially at important events recommended by the Kingdom such as National Children's Day; and (4) joint ritual and prayer events in Tamot which are attended by both Muslims and Buddhists (U.K. Ahmad, pers. comm., 08 November 2017). In their research in Quebec, Tremblay et al. (2018) gave recommendations to make a learning arena of 'living together' for wider and stronger socialisation and negotiation for young people.

In Tamot and its surroundings, there are health volunteer activities participated in by young Muslims and Buddhists. Health volunteers called Asa Sama' Mubaan or Osomo, consisting of five to 10 people who assist the community health centre (Sun Anamay Mubaan Lek Tamboon) in managing community health and hygiene. The volunteers have received training in how to check blood pressure, blood sugar and body temperature, and to recognise symptoms of diseases. They are given duties of recording data on newborn children, giving immunisation injections, monitoring the condition of infants, collecting data on patients who have just finished treatment at the hospital, and reporting on them to nurses or doctors at the community health centre.

Also, the Osomo have an obligation to maintain the cleanliness of the village and provide counselling about clean living to the community (M. Ihsan, pers. comm., 08 November 2017).

At the district level, community health centres have long been established, and some of them have been upgraded to hospitals where doctors are on duty only three days a week. Each community health centre coordinates the village health centre. The person in charge of serving the community at the village health centre is a nurse assisted by five to 10 Osomo, who must be literate (M. Ihsan, pers. comm., 08 November 2017). The activities carried out by young people are very beneficial for the village. Thus, their parents feel happy and support it, while reducing conflicts that sometimes arise among youth and parents.

This form of collaboration between young men and woman also includes sports, such as soccer and sepak takraw. These sports are played together in the district centre building and are participated in by Muslims and Buddhists. In the field of arts, young people from both religions also work together to perform arts, especially to welcome the commemoration of National Children's Day, as documented in Table 2.

Continuous meetings can increase the interest in mutual understanding among various diverse groups in a community. In a meeting, a person will tend to tell stories, engage in dialogue, convey ideas and views about something, perhaps about himself, his family, his career, and even his religion. Telling each other will reveal many things about what they like and what they do not like, what they admire and what they hate, so that they can increase their understanding of each other's thoughts and feelings. This state of affairs can reduce prejudice (Banks 2007), so that the 'deadlock' discussion which often restricts communication can be normalised. For example, in the case of a celebration event held by a Buddhist family, Muslims previously had never been willing to eat the meat served because they thought the practice of slaughtering the animal was inappropriate according to Islam. After there was an agreed negotiation that those who slaughtered animals at any

TABLE 2: Activities for social learning.

\begin{tabular}{lllll}
\hline Number & Activities & Members & Objective & Social learning \\
\hline 1 & Medical volunteer & $\begin{array}{l}\text { Muslim and Buddhist young } \\
\text { men and women }\end{array}$ & $\begin{array}{l}\text { Recording data on newborn children, giving } \\
\text { immunisation injections, monitoring the } \\
\text { condition of infants, collecting data on patients } \\
\text { who have just finished treatment at the hospital, } \\
\text { and reporting on them to nurses or doctors at } \\
\text { the community health centre, maintaining the } \\
\text { cleanliness of the village and providing counselling } \\
\text { about clean living to the community. }\end{array}$ & $\begin{array}{l}\text { Make friends, have an open mind, have a better } \\
\text { understanding of others, appreciate differences, and } \\
\text { preserve the agreed negotiation results. }\end{array}$ \\
2 & $\begin{array}{l}\text { Soccer and sepak } \\
\text { takraw games }\end{array}$ & Muslim and Buddhist youth & $\begin{array}{l}\text { Maintaining health and providing positive } \\
\text { activities for youth. }\end{array}$ & $\begin{array}{l}\text { Make friends, have an open mind, have a better } \\
\text { understanding of others, appreciate differences. }\end{array}$ \\
Art performance & Youth and children & $\begin{array}{l}\text { Commemorating national days, such as National } \\
\text { Children's Day, strengthening patriotism. }\end{array}$ & $\begin{array}{l}\text { Make friends, have an open mind, have a better } \\
\text { understanding of others, appreciate differences. }\end{array}$ \\
\hline
\end{tabular}


celebration event would be Muslims, it changed the situation. Muslims are now willing to eat at a party held by Buddhists.

Percy-Smith (2006) added data from the results of his research that if there is nothing to bridge the differences in social cultural values between the older generation and the younger generation, it can lead to social conflict because young people make their own groups, gather, make noise, and thus disturb the elders. The older generations tend to feel disturbed, neglected, and not supported. Later, the young people thought that they were hated by the elders. In this context, the role of communication and dialogue is very important in order to arouse empathy and mutual understanding. It is also important to rebuild commitment to develop the environment as an inclusive space and a collective culture rather than a place of conflict (Percy-Smith 2006). However, volunteer activities consisting of young Muslims and Buddhists assisting in solving health problems can be a means of meeting one another as well as being a bridge between the old generation and the youth. Percy-Smith examined the relationship of the younger generation with the elders, where conflicts often occur because of differences in sociocultural values. The younger generation like to get together and play loud music and be noisy, making the elders less sympathetic and even in conflict with the youth. After they had been brought together, there was a dialogue which resulted in an agreement that the older generation would provide a special space for young men and women to express themselves when pursuing their hobbies, with some mutually agreed rules (Percy-Smith 2006).

\section{Reinforcement elements of social learning in a multireligious community}

A cultural negotiation process cannot just happen. Each party is certainly based on the existence of in-depth knowledge and experience of each identity. However, mutual understanding can be built. It is in line with the statement that knowledge is cumulative and thus is gained through a collective process. The many and varied experiences which, according to Bandura, are called vicarious experiences can be an amplifier and an important element assisting an individual to learn (Pierce \& Bandura 1977).

Beside varied experiences, the next reinforcing element in learning is the previous success factor, which Bandura called performance accomplishment. In the context of the three cultural negotiation activities, it can be understood that their success in establishing a relationship the previous time made them happy and want to repeat the same experience. The success of negotiation as an experience for an individual is possibly influenced by advice, suggestions, or information received previously, which Bandura called verbal persuasion. Verbal persuasion includes suggestions, advice, warnings, or self-persuasion to explain incomprehensible things and make sense of them (positive thinking). The spirit of negotiating until it succeeds also becomes the actualisation of emotional arousal, which assists in controlling emotions to eliminate negative emotions, such as imagining unpleasant things before they actually happen. For example, they might imagine what would happen if they did not get along well and conflict occurred, and their children and grandchildren would grow up sad and threaten society with destruction.

According to Bandura, there are four reinforcing elements in social learning, namely: (1) vicarious experiences, (2) performance accomplishment, (3) verbal persuasion, and (4) emotional arousal. In his theory, Bandura did not explain in detail the characteristics of the environment which became the medium of learning and explained the four elements of reinforcement in social learning as already mentioned. In the context of a diverse community of religion, culture, and language, the four elements are not yet sufficient as a reinforcement of social learning, because the community has a uniqueness that is different from society in general. In the case of verbal persuasion, for example, an explanation can be added about the sources of values in social learning, such as: (1) moderate values derived from religious teachings, and (2) moderate values taught by the Kingdom. Meanwhile, emotional arousal can be added to the principles of life in overcoming conflicts, such as the existence of trust and winwin solutions.

\section{Moderate values from Islam and Buddhism teachings}

The first meeting of Muslims and Buddhists took place when Muslims came to a place called Sindh, now located in Pakistan. They came to see Buddhist temples and monks. Muhammad ibn Qasin (a general of the Umayyad dynasty) was the first person to arrive there. He wrote to Al-Hajjaj ibn Yusuf (an Umayyad governor): 'What should I do with people who are not Muslim?'

The first thing Al-Hajjaj ibn Yusuf said was: 'Treat them as Ahl Al-Kitab - people with the Book,' referring to the Jews and Christians. The second instruction was: 'Do not attack their monks,' and the third was: 'Do not destroy their temples.' The fourth instruction was: 'Collect jizyah from them.' Jizyah is a per capita tax for non-Muslim free men as a compensation for protection and exemption from military service. This was how Muslims treated Buddhists, long before Westerners came to know Buddhism (Yusuf 2007).

Islam and Buddhism differ from one another in terms of doctrine, but both have existed in social relations with each other for centuries. Muslims and Buddhists have been involved in religious exchanges in their meetings in Central, South and Southeast Asia. Their initial meeting was followed in several cases by the conversion of Buddhists to Islam, as happened in Central and Southeast Asia. But there are also other areas where Buddhism and Islam have continued to coexist along the way, as has happened in India and also on Southeast Asia's mainland, such as some regions in Thailand (Yusuf 2009). The same also occurred between Buddhists and Hindus in Tabanan, Bali (Swasgita 2017) and between Muslims and Christians in Ambon (Qurtuby 2013). 
The Buddhist expression of Majjhima-patipada refers to the idea that Buddhism represents the middle way. The Buddha reached nirvana from within himself based on his own efforts in seeking answers to questions of dukkha [human suffering] and the pursuit of salvation. As for Muhammad peace be upon him - he attained his single spiritual form through revelations from outside himself while trying to understand the meaning of being a human in terms of the purpose of creation and the purpose of life. Yusuf (2009) gives an additional analysis of the meeting between Islam and Buddhism, which is as old as the birth of Islam. The first meeting between Islam and Ashab al-Bidada - the Buddhist community - took place in the middle of $7 \mathrm{AD}$ in the eastern regions of Persia, Transoxiana, Afghanistan, and Sindh. A lot of historical evidence shows that some early Muslims extended the categories of the Qur'an and the Bible in respect of revealed religions to include Hinduism and Buddhism. During the 2nd century of Islam or the 8th century AD, Muslims translated many Buddhist works into Arabic. We can find books in Arabic such as Bilawar wa Budhasaf and Kitab al-Budd (Yusuf 2009).

The occurrence of harmony in the community which is motivated by religious reason was also carried out by Swasgita (2017) between Buddhists and Hindus in Tabanan, Bali, between Muslims and Christians in Ambon (Qurtuby 2013), and between Muslims and Christians in East Africa (Chitwood 2017). Chitwood described the changes in Kenyan Evangelical Christianity and Somali Islam more openly. This shift is due to a confluence of factors including community context, economic pragmatism and religious motivations, and the focus on evangelism does not necessarily preclude peace building.

\section{Moderate values from the Kingdom as learning reinforcement}

Negotiation of identity between religions in the context of nation requires basic values that can be the initial capital for the negotiation process, so that citizens do not hesitate in negotiating because they are protected by their country. Seeing the diversity of religions that are vulnerable to conflict in Thailand, the Kingdom has built three pillars of teaching that can support citizens to learn from each other and understand each other. The three pillars of teaching are intended to build a culture of harmony among citizens in Thailand, especially for employees or teachers who will be assigned to the southern region. They are: (1) Khaochai [understanding], (2) Khaotong [coming in or entering at grass roots level], and (3) Pattana [building] (see Figure 4) (Berggren \& Nilsson 2016).

Khaochai means that when confronting people of a different religion, ethnic origin, or culture, first understand him, his tribe, his religion and culture, and his identity. For example, find out who he is, where he came from, what is being done or studied, or what his favourite thing is, what is considered taboo, and so on (A. Samaale \&
A. Kalupae, pers. comm., 04 November 2017). This understanding is important to be able to adjust in daily sociocultural life.

Khaotong is the attitude when someone has entered at grassroots level. It means that when teachers have understood their students, they can provide good service. At this stage, we can see that the religious leaders were not too strict when communicating the religious doctrine, but were more contextual, such as giving examples of kindness, accustoming children to greet and to make friends of different religions both at school and at home, as well as eating and playing together.

Pattana is the situation of mutual cooperation between religious communities, including the cooperation between religious leaders and religious communities in a multicultural society. This collaboration is carried out especially when each religious group celebrates religious holidays or events, such as when someone is sick or dies, or when all members of the community work together to clean the surrounding environment. The values of cooperation and tolerance between religious communities in Indonesia, for instance, are much influenced by the results of teachings from the government to have tolerance and to cooperate (Hadi et al. 2017). Meanwhile, in Somalia, many people have changed their values through continuous dialogue (Berggren \& Nilsson 2016).

The royal values are intensely socialised community leaders and religious leaders so that they have a strong commitment, because they are generally asked by the community to become mediators or negotiators in solving problems that arise in society (Figure 5). A negotiator must try to create hopes around the negotiating table to offer cooperative steps and to minimise the risks. This requires a strategy in building trust and win-win solutions (Fells 1993).

\section{The role of trust in negotiation and in boosting learning}

Trust is the value of believing and being reliable. Trust often appears in economic research terms which examine the role of trust in various economic successes. More research also examines the role of trust in mutual relations, which creates harmony in sociocultural life (Hoorn 2014). Fukuyama (2002) said trust is a reward from the community for those who

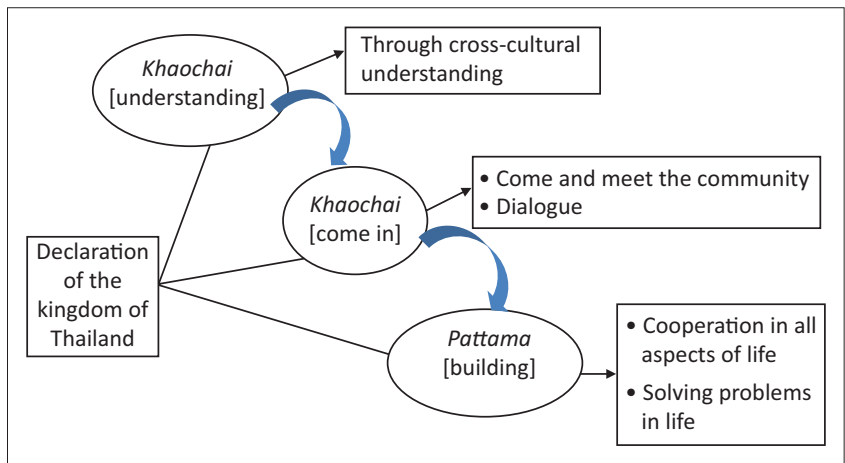

FIGURE 5: Supporting values of appreciating diversities taught by the Kingdom of Thailand. 
behave normally, honestly, and cooperatively based on shared norms and the interests of all members of the community. According to Sztompka (1999), trust is the expectation that other people, groups or institutions with whom we come into contact - interact, cooperate - will act in ways conducive to our well-being.

In this definition, trust contains the concepts of hope, affecting relationships, cooperation, and being supportive. It means that trust is a relationship of mutual support and cooperation towards a common goal. Suwindia's research (2012) in Bali on the relationship between Islam and Hinduism in a multicultural perspective stated that a stronger relationship between Islam and Hinduism can be observed because of the strength of trust, mutual acceptance and exchange of kindness, and strengthening networks in the context of the local regions. Strengthening the meaning of tolerance in religious life and other social life between the Muslim and Hindus in the regions also fosters an awareness of the common ground as a foundation for a life of mutual respect and acceptance.

Another study conducted by Boehnke and Rippl (2012) on trust in neighbouring German and Czech border areas involving 1129 respondents concluded that trust is influenced by a person's relationship experience in childhood, attachment relationships, duration of contact, and the amount of information possessed by each party. In the context of this research, it can also be explained that the Muslims and Buddhists in Tamot, Phattalung, have been successful in establish good relations because each party feels confident that they will not be betrayed and hurt by the other. They feel safe and comfortable, resulting in interactive behaviours that strengthen relationships and help in maintaining those relationships; therefore, trust has been established. This interrelation can increase the duration of the relationship by strengthening commitment and cooperation, so that in the end, trust can be a valuable component when creating good relations. So, in this relationship, trust can reduce prejudice so as to reduce the risk of partnering and building long-term relationships (Qurtuby 2013; Chatterjee 2006; Chitwood 2017).

The results of Boehnke and Rippl's research above can explain further why Tamot people can live in harmony and cooperate with each other, because they feel united by the common ancestor and the spirit to advance their community. In the context of social learning, trust becomes a good reinforcing element in diverse communities, because the cooperative relations that are established break the boundaries of differences, so that efforts to understand each other's identities are increasingly open. Openness because of trust can also support the exchange of information, whether about health, agriculture, farming, plantations or education, or other matters. Trust also makes people feel comfortable in various meetings because there are no worries that they will be hurt or hurt others.

\section{Win-win solution as the approach of negotiation and learning reinforcement}

In the process of interaction among humans, there is often a condition of imbalance or disharmony between the two parties, especially in daily life, as a result of the complexity of life. The condition of disharmony can be natural because of different characteristics of each person, although sometimes there are also parties trying to create a bad atmosphere which disturbs harmony (Tremblay et al. 2018). This is still considered reasonable if they do not harm the public in general. However, if the problem has disturbed people's lives, it needs to be solved immediately, because the problem can drain energy and cause a setback in life experience.

In solving problems, one can use a win-win solution approach, where no party is harmed. The win-lose approach will often result in a lose-lose solution, which means all parties encounter destruction. So, a win-win solution is a frame of mind and heart that always strives to gain or encourage mutual benefit in every human interaction. A winwin solution means a solution that is profitable and satisfies all parties. With a win-win solution, all parties feel good about the decision. Win-win sees life as an arena not of competition but of cooperation (Sobarna 2002).

According to Martin Buber, one of the existentialist philosophers, the win-win solution approach criticises approaches to problem solving between nations that oppose East-West countries, and he refers to this pattern of relations as an 'I-it relationship' (Kramer \& Gawlick 2003). In this pattern of relationship, the other party is considered not a human, but a thing. Therefore, there is no empathy and there is no ability of individuals to understand the world of their relationship partners. A real or genuine relationship between individuals, tribes, nations and civilisations is not an 'I-it relationship' but an 'I-you relationship'. In this relationship, individuals value their relationship partners as subjects who have feelings, thoughts and desires. This relationship, in the end, can solve every problem effectively (Moon et al. 2011; Sobarna 2002).

From this philosophical foundation, Covey (2013) created the win-win solution formula. The problem is that problemsolving patterns that occur in society are often win-lose, especially problems between rulers and subjects, officials in conflict with the people, employers in conflict with employees, and so on. In fact, in reality, the win-lose settlement pattern more often results in a lose-lose situation (no party wins). This is because the win-lose approach creates an atmosphere and a state of injustice that hurts one of the parties and ultimately gives rise to despair for the defeated party. Conditions like this can cause a burning sense of revenge and emotional instability so that revenge is carried out undermining human values, and a lose-lose situation arises (Sobarna 2002). Thus, a win-win solution is a mind-set and heart that always strives to gain profit, 


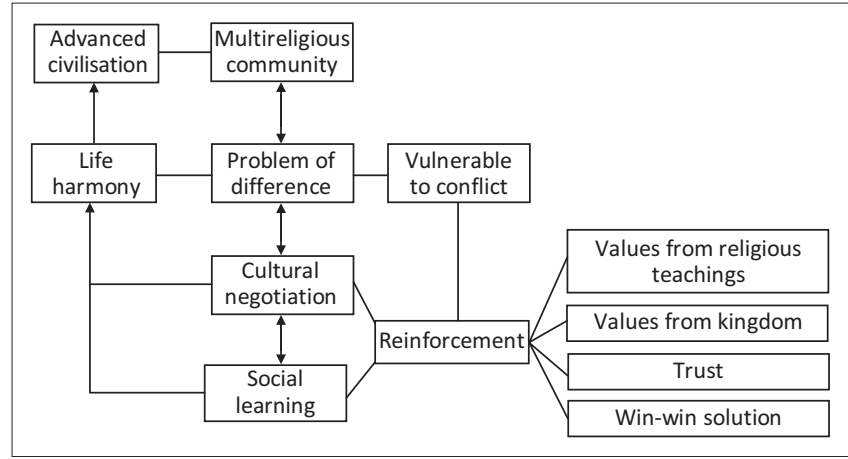

FIGURE 6: Cultural negotiation, social learning, and reinforcement elements in multireligious society.

satisfaction, and happiness together in every problemsolving effort (Brett et al. 2017).

In the context of social learning, a win-win solution is also important as a model of problem solving that can be imitated by the young generation as well as supporting a comfortable and peaceful environment. This is very important in the context of a multicultural society in order to avoid conflicts. To achieve a win-win situation, negotiation often requires a third party, called a mediator. Both parties who have problems and the mediators are required to have a strong attitude of self-control, and not be easily carried by the flow of disappointment, sadness, compassion, and anger of other people or parties. Problem solving can also be effective if the element of self-control is put forward by all parties. The element of self-control is also important as an amplifier in social learning which Bandura calls emotional arousal, which means controlling emotions to eliminate negative emotions, such as imagining unpleasant things before they actually occur. As before, imagine if people did not get along well and conflicts occurred; their children would bear sadness on their shoulders and threaten destruction.

In this research, we have successfully identified several ways of solving problems with a win-win solution, including: (1) the problem of a shared burial place, (2) the problem of joint prayer, so that there is no one-sided ownership claim of the burial place, (3) the problem of making halal food for Muslims, (4) the problem of Islamic prayer around the temple, and (5) the problem of dogs in Muslim settlement, among other matters.

Thus, it has been analysed that there are four elements of strengthening social learning in diverse societies, in terms of religion, ethnicity and language, namely: (1) moderate values derived from the teachings of the Islamic Ummatan Wasatan and Buddhist Majjhima-patipada, (2) moderate values taught by the Kingdom, (3) the existence of trust among citizens, and (4) the existence of a win-win solution to problem solving. The four elements of reinforcement in learning are the development of Bandura's theory which has not explicitly discussed social learning in diverse societies, so this finding is a development of the Bandura theory, as shown in Figure 6.

\section{Conclusion}

The description of the community which has a building construction of tolerance and harmony of locality can be seen in the 'Two Religion Community Life' region of Phattalung province, Thailand. The harmony was built by cultural negotiations that have been happening continuously for decades. A community that takes the path of peace and living in harmony with mutual trust and overcomes the problem in a win-win solution can be a medium of social learning from generation to generation. In Muslim and Buddhist communities, there are religious values that try to bridge the differences, namely in the teachings of the Islamic Ummatan Wasatan and the teachings of the Buddhist Majjhima-patipada. Through various cultural efforts, they continuously look for peace. They often negotiate their authenticity and identity in order to mingle for the sake of creating social harmony, such as annual prayer rituals performed jointly by Muslims and Buddhists, slaughtering animals for parties, food bartering, and animal care. Social learning in a multireligious society is also strengthened by individual commitments to moderate values taught by the country, the existence of trust among citizens, and a win-win solution to any problem which arises.

\section{Acknowledgements}

This article was compiled due to the good assistance of and cooperation with the Research and Community Service office (LPPM) UIN Sunan Kalijaga Yogyakarta in the scheme of Postdoctoral Research Program UIN Sunan Kalijaga 2017. I would like to thank Prof. K.H. Yudian Wahyudi, MA, PhD as the Rector of UIN Sunan Kalijaga and Prof. Al Makin, MA, PhD as chairman of LPPM UIN Sunan Kalijaga Yogyakarta.

\section{Competing interests}

The authors have declared that no competing interest exist.

\section{Authors' contributions}

All authors contributed equally to this work.

\section{Ethical consideration}

This article followed all ethical standards for a research without direct contact with human or animal subjects.

\section{Funding information}

This research received a grant from The Research and Community Service (LPPM), UIN Sunan Kalijaga Yogyakarta, Indonesia.

\section{Data availability statement}

Data sharing is not applicable to this article as no new data were created or analysed in this study. 


\section{Disclaimer}

The views and opinions expressed in this article are those of the authors and do not necessarily reflect the official policy or position of any affiliated agency of the authors.

\section{References}

Abdullah, M.A., 2013, Agama, Ilmu dan Budaya: Paradigma Integrasi-Interkoneksi Keilmuan [Religion, science and culture: Scientific integration-interconnection paradigm], Akademi Ilmu Pengetahuan Indonesia, Jakarta, ID.

Ahmad, U.K., 2017, 08 November, Wawancara tentang kegiatan masyarakat sekitar Tamot untuk melestarikan sikap saling menghargai [Personal interview of Tamot community activities to preserve the attitude of appreciating others].[Personal communication].

Ahmad, U.K., 2017, 06 November, Wawancara tentang Upacara ritual do'a bersama Muslim dan Buddha di Kawasan "Two Religion Community Life", Tamot, Phattalung [Personal interview of Muslims-Buddhists praying ritual in Two Phattalung [Personal interview of Muslims-Buddhists praying ritual
Religion Community Life, Tamot, Phattalung]. [Personal communication].

Ahmad, U.K., 2017, 07 November, Wawancara tentang negosiasi kultural untuk memecahkan masalah hidup sehari-hari umat Islam dan Buddha [Personal interview of cultural negotiation to solve daily problems of Muslim and Buddhist]. [Personal communication].

Altun, Ö.S., Karakas, S.A., Olqun, Z. \& Polat, H., 2018, 'An investigation of the relationship between schizophrenic patients' strength of religious faith and adherence to treatment', Archives of Psychiatric Nursing 32(1), 62-65. https:// doi.org/10.1016/j.apnu.2017.09.015

Appleby, R.S., 2000, The ambivalence of the sacred, religion, violence, and reconciliation, Rowman \& Littlefield Publishers Inc., New York, NY.

Banks, J.A., 2007, An introduction to multicultural education, Allyn \& Bacon Incorporated, Boston, MA.

Berggren, N. \& Nilsson, T., 2016, 'Tolerance in the United States: Does economic freedom transform racial, religious, political and sexual attitudes?', European Journal of Political Economy 45(5), 53-70. https://doi.org/10.1016/ j.ejpoleco.2016.06.001

Blute, M., 1981, 'Learning, social learning, and sociocultural evolution: A comment on langton', American Journal of Sociology 86(6), 1401-1406. https://doi. org/10.1086/227390

Boehnke, K. \& Rippl, S., 2012, 'General and "neighbourly" trust in border regions: An analysis of the influence of disintegration experience and of self-enhancement mentalities in the German-Czech border regions', Sociologický Časopis/Czech Sociological Review 48(6), 1075 s.

Brett, J.M., 2010, 'Culture and negotiation', International Journal of Psychology 35(2) 97-104. https://doi.org/10.1080/002075900399385

Brett, J.M., Gunia, B.C. \& Teucher, B.M., 2017, 'Culture and negotiation strategy: A framework for future research', Academy of Management Perspectives 31(4) framework for future research', Academy of Ma

Bungin, M.B., 2007, Penelitian Kualitatif [Qualitative research], Prenada Media Group, Jakarta.

Chatterjee, I., 2006, 'Applying models of conflict negotiation to the Hindu-Muslim conflict in Ahmedabad, India', International Journal of Conflict Management 17(2), 154-174. https://doi.org/10.1108/10444060610736620

Chitwood, K., 2017, 'Somalis as Samaritans: A Glimpse into Christian-Muslim Relations in Eastern Africa from the perspective of evangelical Kenyan Christians', Islam and Christian-Muslim Relations 28(1), 69-84. https://doi.org/10.1080/095 96410.2017.1286751

Christie, I., Gunton, R.M. \& Hejnowicz, A.P., 2019, 'Sustainability and the common good: Catholic Social Teaching and 'Integral Ecology' as contributions to framework of social values for sustainability transitions', Sustainability Science 14(5), 1343-1354. https://doi.org/10.1007/s11625-019-00691-y

Comberti, C., Thornton, T.F., Korodimou, M., Shea, M. \& Riamit, K.O., 2019, 'Adaptation and resilience at the margins: Addressing indigenous peoples' marginalization at international climate negotiations', Environment: Science and Policy for Sustainable Development 61(2), 14-30. https://doi.org/10.1080/00139157.2019.1564213

Covey, S.R., 2013, The 7 habits of highly effective people: Powerful lessons in personal change, Simon and Schuster, New York.

Fells, R.E., 1993, 'Developing trust in negotiation', Employee Relations 15(1), 33-45. https://doi.org/10.1108/01425459310024910

Frounfelker, R., Assefa, M.T., Smith, E., Hussein, A. \& Betancourt, T., 2017, “'We would never forget who we are": Resettlement, cultural negotiation, and family relationships among Somali Bantu refugees', European Child \& Adolescent Psychiatry 26(11), 1387-1400. https://doi.org/10.1007/s00787-017-0991-1

Frydenlund, I. \& Jerryson, M., 2020, 'An introduction: Buddhist-Muslim relations in a Theravada World', in I. Frydenlund \& M. Jerryson (eds.), Buddhist-Muslim relations in a Theravada World, pp. 1-21, Palgrave Macmillan, Singapore, SG.

Fukuyama, F., 2002, Trust, Ruslani, Transl., Qalam, Yogyakarta, ID.

Gutmann, A., 2003, Identity in democracy, Princeton University Press, Princeton, NJ.

Hadi, D.W., Dokhi, M., Siagian, T.H., Rini, R. \& Sukim, 2017, Analisis faktor-faktor yang mempengaruhi sikap toleransi di Indonesia [Analysis of factors affecting tolerance attitudes in Indonesia], Pusat Data dan Statistik Kemetrian Pendidikan dan Kebuyaan RI, Jakarta, ID.
Hansen, D.T., 2002, 'Dewey's conception of an environment for teaching and learning', Curriculum Inquiry 32(3), 267-280. https://doi.org/10.1111/1467-873X.00228

Hidayati, N., 2016, 'Konsep integrasi tripusat pendidikan terhadap kemajuan masyarakat [The concept of the integration of the education center for community progress]', Edukasia: Jurnal Penelitian Pendidikan Islam 11(1), 1-10. https://doi. org/10.21043/edukasia.v11i1.811

Hoorn, A.V., 2014, 'Trust radius versus trust level: Radius of trust as a distinct trust construct', American Sociological Review 79(6), 1256-1259. https://doi.org/10. $1177 / 0003122414555398$

Horstmann, A., 2011, 'Living together: The transformation of multi-religious coexistence in southern Thailand', Journal of Southeast Asian Studies 42(3), 487-510.

Ihsan, M., 2017, 08 November, Wawancara Tugas Volunteer Kesehatan untuk Melayani Masyarakat Bidang Kesehatan [Interview with the Volunteer Health Task to Serve the Public Health Sector]. [Personal communication].

Kramer, K. \& Gawlick, M., 2003, Martin Buber's I and Thou: Practicing living dialogue, Paulist Press, New York.

Kung, H., 1997, 'A global ethic in an age of globalization', Business Ethics Quarterly 7(3), 17-32. https://doi.org/10.2307/3857310

Laiti, O.K. \& Frangou, S.M., 2019, 'Social aspects of learning: Sámi people in the circumpolar north', International Journal of Multicultural Education 21(1), 5-21.

Miles, M.B., Huberman, A.M. \& Saldana, J., 2018, Qualitative data analysis, a methods source book, 4th edn., Sage Publications, London, UK.

Moon, S., Jambert, E., Chlids, M. \& Von-Schoen-Anangerer, T., 2011, 'A win-win solution?: A critical analysis of tiered pricing to improve access to medicines in developing countries', Globalization and Health 7(1), 39. https://doi.org/10. 1186/1744-8603-7-39

Nabavi, R.T., 2012, 'Bandura's social learning theory \& social cognitive learning theory', Theory of Developmental Psychology 1-24.

Natanson, M., 1966, 'The phenomenology of Alfred Schutz', Masyarakat: Jurnal Sosiologi 9(1-4), 147-155. https://doi.org/10.1080/00201746608601455

Nindito, S., 2013, 'Fenomenologi Alfred Schutz: Studi tentang konstruksi makna dan realitas dalam ilmu sosial [Alfred Schutz's Phenomenology: Study of the construction of meaning and reality in social science]', Jurnal Ilmu Komunikasi 2(1), 79-94. https://doi.org/10.24002/jik.v2i1.254

Nugroho, O.H.P., 2014, 'Meretas damai di tengah keberagaman: Mengembangkan pendidikan Kristiani untuk perdamaian dalam perspektif multikulturalisme [Hacking peace amid diversity: Developing Christian education for peace in the perspective of multiculturalism]', Gema Teologi 38(2), 143-170.

Oman, D., 2013, 'Spiritual modeling and the social learning of spirituality and religion', in APA handbook of psychology, religion, and spirituality (Vol 1): Context, theory, and research, pp. 187-204, American Psychological Association, Washington DC. https://doi.org/10.1037/14045-010

PeoPlaid, 2018, 08 November, Phatthalung Province Thailand - PeoPlaid Profile, viewed 24 August 2019, from https://peoplaid.com/2018/11/08/phatthalungprovince/.

Percy-Smith, B., 2006, 'From consultation to social learning in community participation with young people', Children, Youth and Environments 16(2), 153-179, viewed 31 March 2018, from http://www.jstor.org/stable/10.7721/chilyoutenvi.16.2.0153.

Pierce, W.D. \& Bandura, A., 1977, 'Social learning theory', Canadian Journal of Sociology/ Cahiers Canadiens de Sociologie 2(3), 321. https://doi.org/10.2307/3340496

Qurtuby, S.A., 2013, 'Peacebuilding in Indonesia: Christian-Muslim Alliances in Ambon Island', Islam and Christian-Muslim Relations 24(3), 349-367. https://doi org/10.1080/09596410.2013.785091

Radhakrishnan, S., 2019, Religion, science and culture, Orient Paperbacks, New Delhi, IN.

Rissanen, I., 2020, 'Negotiations on inclusive citizenship in a post-secular school: Perspectives of "Cultural Broker" Muslim parents and teachers in Finland and Sweden', Scandinavian Journal of Educational Research 64(1), 135-150. https:// doi.org/10.1080/00313831.2018.1514323

Sadr, O., 2020, Negotiating cultural diversity in Afghanistan, Taylor \& Francis, London.

Saffari, S., 2019, 'Ali Shariati and Cosmopolitan Localism', Comparative Studies of South Asia, Africa and the Middle East 39(2), 282-295.

Samaale, A., \& Kalupae, A., 2017, November 4. Wawancara tentang nilai-nilai dasar toleransi antar umat beragama yang diserukan oleh Kerajaan Thailand [Personal interview on basic values of tolerance among religions in Thailand Kingdom]. [Personal communication].

Shanks, K., 2019, 'The politics of IDP education provision: Negotiating identity and schooling in the Kurdistan Region of Iraq', International Migration 57(2), 32-47. https://doi.org/10.1111/imig.12545

Shusterman, R., 2010, 'Dewey's art as experience: The psychological background', The Journal of Aesthetic Education 44(1), 26-43. https://doi.org/10.1353/jae.0.0069

Silvestri, S. \& Mayall, J., 2015, Role of religion in conflict peacebuilding, The British Academy, London, UK.

Sobarna, A., 2002, 'Pendekatan win-win solution dalam mengatasi terorisme internasional: Tantangan dan peluang [A win-win solution approach to dealing with international terrorism: Challenges and opportunities]', Mimbar: Jurnal Sosial dan Pembangunan 18(4), 379-398.

Stromquist, N.P., 2014, 'Freire, literacy and emancipatory gender learning', New Times 60(4), 545-558. https://doi.org/10.1007/s11159-014-9424-2

Suwindia, I.G., 2012, 'Relasi Islam dan Hindu perspektif masyarakat Bali [The relation between Islam and Hinduism in Balinese perspective]', Jurnal Al-Ulum 12(1), 53-76. 
Swasgita, I.P.H.Y., 2017, 'Realisasi toleransi antar umat Hindu dan Buddha di Pura Pusering Jagat Panca Tirta Desa Pakaraman Kembang Merta Desa Candikuning Kecamatan Baturiti Kabupaten Tabanan [Realization of tolerance between Hindus and Buddhists in Pura Pusering Jagat Panca Tirta Pakaraman Kembang Merta Village Candikuning Village Baturiti District Tabanan Regency]', Jurnal Penelitian
Agama Hindu 1(2), 263-269.

Sztompka., P., 1999, Trust: A sociological theory, University Press, Cambridge, UK.

Thornton, T.F., Puri, R.K., Bhagwat, S. \& Howard, P., 2019, 'Human adaptation to biodiversity change: An adaptation process approach applied to a case study from southern India', Ambio 48(12), 1431-1446. https://doi.org/10.1007/s13280-019-01225-7

Tremblay, S., Magnan, M.O. \& Levasseur, C., 2018, 'Religion and negotiation of the boundary between majority and minority in Québec: Discourses of young Muslims in Montréa CÉGEPs', Education Sciences 8(4), 183. https://doi.org/10.3390/educsci8040183

Tu, Y.-T. \& Chih, H.-C., 2011, 'An analysis on negotiation styles by religious beliefs', International Business Research 4(3), 243-253. https://doi.org/10.5539/ibr.v4n3p243
Wertheim, E., 2017, Negotiations and resolving conflicts: An overview, College of Business Administration, Northeastern University, viewed 10 August 2019, from http://web.cba.neu.edu/ ewertheim/interper/negot3.html.

Yusuf, I., 2007, 'The Southern Thailand conflict and the Muslim world', Journal of Muslim Minority Affairs 27(2), 319-339. https://doi.org/10.1080/1360200070 1536232

Yusuf, I., 2009, 'Dialogue between Islam and Buddhism through the Concepts Ummatan Wasațan (The Middle Nation) and Majjhima-Patipada (The Middle Way)', Islamic Studies 48(3), 367-394.

Zaw, H.T., 2019, 'Culture communication: Is an effective support for conflict resolution and peace process in Myanmar', International Journal of Social Science Studies 7(2), 95-103. https://doi.org/10.11114/ijsss.v7i2.4095

Zhao, Z.J., Chen, H.H. \& Li, K.W., 2020, 'Management of interpersonal conflict in negotiation with Chinese: A perceived face threat perspective', Group Decision and Negotiation 29(1), 75-102. https://doi.org/10.1007/s10726-019-09645-2 